\title{
UJI KONSENTRASI DAN LAMA PERENDAMAN EKSTRAK BUAH MAHKOTA DEWA SEBAGAI MOLUSISIDA NABATI TERHADAP MORTALITAS HAMA KEONG MAS (Pomacea canaliculata Lamarck) \\ (Concentration Test and Submersion Time of God Crown Extract as Bio Molluscicide On Golden Snail Mortalities Pomacea canaliculata Lamarck)
}

\author{
Anna Farisa ${ }^{1}$, Muhammad Sayuthi ${ }^{2}$, Alfian Rusdy ${ }^{2^{*}}$ \\ ${ }^{1}$ Program Studi Agroteknologi, ${ }^{2}$ Program Studi Proteksi Tanaman Fakultas Pertanian, Universitas Syiah Kuala
}

\begin{abstract}
Abstrak Keong Mas adalah salah satu hama utama pada areal pertanaman padi yang tingkat serangannya tergolong cukup tinggi hingga dapat menyebabkan gagal panen. Buah mahkota dewa merupakan tanaman yang berpotensi sebagai pestisida nabati yang diketahui mengandung zat aktif seperti alkaloid, tannin, flavonoid, fenol, saponin, dan minyak atsiri. Tujuan dari penelitian ini adalah untuk mengetahui konsentrasi dan lama perendaman ekstrak dari buah mahkota dewa yang efektif terhadap mortalitas keong mas (Pomacea. canaliculata). Penelitian ini menggunakan metode Rancangan Acak Lengkap (RAL) pola faktorial yang terdiri dari 2 faktor. Faktor pertama adalah konsentrasi buah mahkota dewa sebanyak $5 \mathrm{~g}, 10 \mathrm{~g}$ dan $15 \mathrm{~g}$ dan faktor kedua adalah lama perendaman selama 24 jam, 48 jam, dan 72 jam. Pengamatan meliputi mortalitas keong mas, penghambatan makan dan rata-rata waktu kematian. Hasil pengamatan penggunaan ekstrak buah mahkota dewa sebagai molusisida nabati dengan konsentrasi $15 \mathrm{~g} / \mathrm{l}$ air dan lama perendaman 72 jam (K3L3) efektif untuk menurunkan daya hidup (motalitas) keong mas hingga mencapai 89,09\% dan penghambat makan keong mas tertinggi terdapat pada kombinasi perlakuan K1L2 dengan persentase nilai 47,90\%, sedangkan untuk kecepatan waktu kematian keong mas setelah dilakukan pengaplikasian menggunakan ekstrak buah mahkota dewa berkerja efektif pada perlakuan kosentrasi K3 dan lama perendaman efektif pada perlakuan L3.
\end{abstract}

Kata kunci: Keong mas, buah mahkota dewa, molusisida nabati, mortalitas.

\begin{abstract}
The golden snail is one of the main pests in rice cultivation area which has a high level of attack so that it can cause crop failure. God's crown fruit is a plant that has the potential as a bio pesticide which is known containing chemical substances such as alkaloids, tannins, flavonoids, phenols, saponins, and essential oils. The purpose of this research was to determine the concentration and submersion time of extracts from the fruit of god crown which is effective against the mortality of golden snails (Pomacea canaliculata). Research method used was experimental method using Completely Randomized Design method (RAL) with factorial pattern consisting of 2 factors. The first factor was $5 \mathrm{~g}, 10 \mathrm{~g}$ and $15 \mathrm{~g}$ of the concentration of the god crown and the second factor were 24 hours, 48 hours and 72 hours of submersion time. The observation included golden snail mortality, feeding inhibition and the average time of mortality. The results of observations of the usage of the god crown fruit extract as bio molluscicide with a concentration of $15 \mathrm{~g} / 1$ of water and 72 hours of submersion time (K3L3) were effective to reduce the life (mortality) of snails to reach $89.09 \%$ and the highest snail eating inhibitors were found in the combination K1L2 treatment with a percentage value of $47.90 \%$, while for the golden snail average time of mortality after application using fruit extract of god crown worked effectively on the treatment of $\mathrm{K} 3$ concentration and the submersion time is effective in $\mathrm{L} 3$ treatment.
\end{abstract}

Keywords: Golden snail, god's crown fruit, bio pesticide, mortality.

\section{PENDAHULUAN}

Keong mas (Pomacea canaliculata Lamarck) termasuk famili Ampullaridae. Hewan ini merupakan spesies asli dari Amerika Selatan yang masuk secara ilegal ke Asia pada tahun 1979, P. canaliculata pada dasarnya berasal dari daerah tropis dan subtropis, termasuk diantaranya Negara Argentina, Bolivia, Paraguay, dan Brasil serta Indonesia (Cowie, 2003).

Keong mas yang lepas ke sawah berkembang biak dengan cepat, sawah menjadi habitat yang sesuai bagi perkembangan hidup keong mas dan membuat populasinya terus meningkat dalam waktu yang relatif cepat, sehingga tidak membutuhkan waktu lama untuk keong mas merusak pertanaman padi di sawah. Luas areal pertanaman padi yang dirusak keong mas pada tahun 2007 mencapai lebih dari 22.000 ha Oleh sebab itu, keong mas berubah status dari hewan peliharaan menjadi hama tanaman padi. Pada tingkat serangan yang berat, 
keong mas mampu merusak banyak rumpun padi, sehingga petani harus mananam ulang. (Direktorat Perlindungan Tanaman Pangan, 2008).

Menurut Suharto (2002), di daerah Jawa Barat sampai pada tahun 1992 tidak ditemukan adanya keong mas di sawah namun hanya dipelihara di kolam. Pada tahun 1995 sudah ada 12 kabupaten yang tanaman padinya diserang oleh hama keong mas. Namun, empat tahun kemudian meningkat hingga mencapai 16 kabupaten. Penyebarannya menjadi lebih luas tiap tahunnya tidak hanya di sawah yang berdrainase buruk, tetapi juga di sawah yang memiliki sistem irigasi teratur.

Sejak hama keong mas ini merebak, sudah banyak cara dilakukan untuk mengendalikan hama tersebut seperti menggunakan pestisida, pengendalian secara mekanis maupun biologis. Pestisida sendiri merupakan bahan atau zat kimia yang digunakan untuk membunuh hama, baik yang berupa tumbuhan, serangga, maupun hewan lain yang bersifat merugikan secara ekonomi di lingkungan kita. Pestisida digolongkan menjadi beberapa jenis sesuai fungsinya seperti, insektisida, herbisida, nematisida, fungisida, molusisida dan rodentisida. Molusisida sendiri adalah pestisida untuk mengendalikan siput (mollusca), siput telanjang, siput setengah telanjang, sumpil, bekicot (Djojosumarto, 2008). Didasari oleh banyaknya jenis tumbuhan yang dapat berpotensi sebagai pestisida nabati, Kertoseputro et al. (2007) menyatakan potensi tanaman sebagai sumber pestisida nabati sebagai alternatif pengendalian keong mas cukup tepat. Hal ini sesuai dengan Peraturan Pemerintah (PP) No. 6 tahun 1995 pasal 19 yang menyatakan bahwa penggunaan pestisida dalam rangka pengendalian organisme pengganggu tanaman (OPT) merupakan alternatif terakhir dan dampak yang ditimbulkan harus ditekan seminimal mungkin. Pestisida nabati sendiri memiliki banyak kelebihan diantaranya mudah terurai, tidak meninggalkan residu pada tanaman (produk pertanian), tidak mencemari lingkungan, biayanya relatif terjangkau, dan toksisitas rendah sehingga relatif aman terhadap makhluk hidup di sekitarnya (Isman 2008).

Tanaman yang berpotensi sebagai molusisida nabati salah satunya adalah buah mahkota dewa. Mahkota dewa (Phaleria macrocarpa) tergolong jenis tanaman obat yang dikonsumsi sebagian besar masyarakat Indonesia. Mahkota dewa merupakan tanaman perdu yang tumbuh dari dataran rendah hingga 1200 meter diatas permukaan laut. Masyarakat Indonesia selama ini memanfaatkan buah mahkota dewa (P. macrocarpa) sebagai bahan baku obat-obatan untuk menyembuhkan berbagai macam penyakit, seperti penyakit ginjal, kencing manis, tekanan darah tinggi, sampai dengan penyakit kanker.

Buah mahkota dewa ( $P$. macrocarpa) dapat dimanfaatkan sebagai pestisida nabati dan sebagai bahan obat-obatan untuk kebutuhan medis. Kandungan senyawa kimia buah mahkota dewa terdiri oleh alkaloid $0,55 \%$, saponin $20,4 \%$, polifenol $0,23 \%$, serta flavonoid $0,44 \%$ dimana senyawa saponin dapat menghasilkan zat yang beracun (Sumastuti, 2009).

Berdasarkan hasil penelitian Arsyadana (2014) Konsentrasi molusisida nabati biji buah mahkota dewa sebanyak $15 \mathrm{~g}$ dengan lama fermentasi 5 hari efektif dalam mengendalikan hama keong mas dikarenakan Intensitas kerusakan tanaman padi semakin menurun pada perlakuan molusisida nabati mahkota dewa 15 g dengan lama fermentasi 5 hari, dan juga pada perlakuan tersebut intensitas kerusakan tanaman padi semakin menurun. Berdasarkan uraian di atas maka perlu dilakukan penelitian mengenai konsentrasi dan lama perendaman ekstrak buah mahkota dewa sebagai molusisida nabati terhadap mortalitas keong mas ( $P$. canaliculata).

\section{METODE PENELITIAN}

Penelitian ini dilaksanakan di Penelitian ini dilaksanakan di Laboratorium Hama Tumbuhan Program Studi Proteksi Tanaman dan Laboratorium Analisis Pangan dan Hasil 
Pertanian Program Studi Teknologi Hasil Pertanian Fakultas Pertanian Universitas Syiah Kuala.

\section{MATERI DAN METODE}

\section{Alat dan Bahan}

Alat-alat yang digunakan dalam penelitian ini adalah gelas ukur, stoples kaca, stoples plastik, wadah uji (timba volume 10 liter), saringan, ember, pisau, telenan, gunting, timbangan analitik, penggaris, kamera, batang pengaduk, rotary evaporator, jaring nyamuk, kawat, corong, cawan petri, spatula, dan alat tulis.

Bahan yang digunakan dalam penelitian ini adalah buah mahkota dewa yang matang (kulit buah berwarna merah), methanol 70\%, pakan keong berupa daun padi muda berumur 3 minggu, kertas label, air, dan keong mas dewasa (sudah mencapai diameter cangkang $2 \mathrm{~cm}$ ).

\section{Rancangan Penelitian}

Penelitian ini menggunakan metode Rancangan Acak Lengkap (RAL) pola faktorial yang terdiri dari 2 faktor. Faktor pertama adalah konsentrasi ekstrak buah mahkota dewa sebanyak $5 \mathrm{~g}, 10 \mathrm{~g}$ dan $15 \mathrm{~g}$ dan faktor kedua adalah lama perendaman selama 24 jam, 48 jam, dan 72 jam. dengan 9 kombinasi perlakuan dan masing-masing perlakuan dilakukan sebanyak 3 kali ulangan sehingga diperoleh 27unit percobaan. Adapun Susunan perlakuan sebagai berikut:

Tabel 1. Susunan kombinasi perlakuan

\begin{tabular}{|c|c|c|c|c|c|c|}
\hline NO & Perlakuan & \multicolumn{4}{|c|}{ Konsentrasi Molusisida Nabati } & Lama Perendaman \\
\hline 1 & K1L1 & \multicolumn{4}{|c|}{ Ekstrak Buah Mahkota Dewa, 5g/liter } & 24 Jam \\
\hline 2 & K1L2 & \multicolumn{4}{|c|}{ Ekstrak Buah Mahkota Dewa, 5g/liter } & $48 \mathrm{Jam}$ \\
\hline 3 & K1L3 & \multicolumn{4}{|c|}{ Ekstrak Buah Mahkota Dewa, 5g/liter } & 72 Jam \\
\hline 4 & K2L1 & $\begin{array}{l}\text { Ekstrak } \\
10 \mathrm{~g} / \mathrm{liter}\end{array}$ & Buah & Mahkota & Dewa, & $24 \mathrm{Jam}$ \\
\hline 5 & K2L2 & $\begin{array}{l}\text { Ekstrak } \\
10 \mathrm{~g} / \mathrm{liter}\end{array}$ & Buah & Mahkota & Dewa, & $48 \mathrm{Jam}$ \\
\hline 6 & K2L3 & $\begin{array}{l}\text { Ekstrak } \\
10 \mathrm{~g} / \mathrm{liter}\end{array}$ & Buah & Mahkota & Dewa, & 72 Jam \\
\hline 7 & K3L1 & $\begin{array}{l}\text { Ekstrak } \\
15 \mathrm{~g} / \mathrm{liter}\end{array}$ & Buah & Mahkota & Dewa, & $24 \mathrm{Jam}$ \\
\hline 8 & K3L2 & $\begin{array}{l}\text { Ekstrak } \\
15 \mathrm{~g} / \mathrm{liter}\end{array}$ & Buah & Mahkota & Dewa, & $48 \mathrm{Jam}$ \\
\hline 9 & K3L3 & $\begin{array}{l}\text { Ekstrak } \\
15 \mathrm{~g} / \mathrm{liter}\end{array}$ & Buah & Mahkota & Dewa, & 72 Jam \\
\hline
\end{tabular}

\section{Prosedur Penelitian}

\section{Pembiakan dan Pemeliharaan Keong Mas Pomacea canaliculata}

Telur keong mas diambil dari persawahan di Gampong Blangkrueng Kecamatan Baitussalam Aceh Besar, kemudian dibawa ke Gampong Lingke Kecamatan Syiah Kuala Kota Banda Aceh untuk dibiakkan. Telur keong mas yang telah diambil dari persawahan tersebut dimasukan ke dalam ember yang telah berisi air sepertiga bagian, lalu tutup bagian atas ember dengan jaring nyamuk menggunakan kawat. Keong mas dibiarkan hingga menetas setelah menetas keong mas harus diberikan pakan padi muda setiap harinya. Diamater keong 
emas yang digunakan pada penelitian ini berukuran $2 \mathrm{~cm}$. Pembiakan (pemurnian) dilakukan agar didapatkan kelompok keong mas yang seragam.

\section{Penyedian Tanaman Pakan Keong Mas}

Tanaman pakan yang digunakan untuk makanan hama keong mas selama proses pembiakan, pemeliharaan, dan penelitian ialah tanaman padi varietas ciherang berumur \pm 21 hari .

\section{Pembuatan Ekstrak Buah Mahkota Dewa}

Buah mahkota dewa diperoleh dari Desa Garot Kecamatan Darul Imarah Kabupaten Aceh Besar. Buah mahkota dewa matang yang diperoleh dibawa ke Laboratorium Hama Tumbuhan Program Studi Proteksi Tanaman untuk diproses. Buah mahkota dewa matang dicuci bersih, lalu ditiriskan dan ditimbang (sebanyak $7 \mathrm{~kg}$ ), kemudian buah dirajang halus lalu dimasukkan ke dalam stoples kaca, dan ditambahkan pelarut methanol 70\% sebanyak 14 liter, selanjutnya direndam (maserasi) selama 4 hari dan diaduk setiap 1 kali 24 jam. Setelah itu hasilnya disaring menggunakan corong yang dilapisi kain kasa dan ditampung ke dalam stoples plastik. Hasil larutan yang sudah didapat tadi dibawa ke Laboratorium Analisis Pangan dan Hasil Pertanian Program Studi Teknologi Hasil Pertanian Fakultas Pertanian Universitas Syiah Kuala untuk diuapkan dengan menggunakan rotary evaporator pada suhu $50^{\circ} \mathrm{C}$ selama 4 jam hingga mendapatkan ekstrak yang berupa fraksi kasar dalam bentuk gel.

\section{Aplikasi Ekstrak Molusisida Nabati}

Keong mas dimasukan ke dalam wadah uji (timba) berukuran volume 10 liter yang sudah berisikan air, selanjutnya ekstrak buah mahkota dewa dimasukkan ke wadah percobaan sesuai dengan susunan kombinasi perlakuan yang telah ditetapkan (Tabel 1). Keong mas tetap diberi pakan daun padi muda segar sebanyak 10 gram per ember, dan diganti setiap harinya.

\section{Peubah yang diamati}

\section{Mortalitas Keong Mas}

Pengamatan mortalitas keong mas dilakukan dengan menghitung jumlah keong mas yang mati akibat perlakuan dan diamati 1, 2, dan 3 hari setelah aplikasi (HSA). Mortalitas keong mas yang mati ditandai dengan ciri cangkang yang menutup, mengambang dan mengeluarkan lendir. Mortalitas keong mas dihitung dengan rumus yaitu:

$$
\mathbf{P O}=\frac{r}{n} \times 100
$$

Keterangan:

$\mathrm{P}_{0}=$ Mortalitas keong mas

$\mathrm{r}$ = Jumlah keong mas yang mati

$\mathrm{n}=$ Jumlah keong mas yang diamati

\section{Persentase Penghambatan Makan}

Pengamatan dilakukan pada 1, 2, 3, dan 4 hari setelah aplikasi (HSA). Pengamatan dilakukan dengan cara, daun padi yang tersisa dalam wadah uji diangkat seluruhnya, kemudian ditiriskan hingga daun padi kering dari sisa-sisa air, lalu ditimbang berat daun padi berat awal pakan dan berat akhir pakan setiap hari sampai hari ke 4 dengan menggunakan neraca digital. Perhitungan persentase penghambat makan menggunakan rumus yaitu: 


$$
\mathbf{P M}=\frac{\mathrm{Bk}-\mathrm{Bp}}{\mathrm{Bk}+\mathrm{Bp}} \times 100
$$

Keterangan:

$\mathrm{PM} \quad=$ Penghambat makan $(\%)$

$\mathrm{Bk}=$ Berat awal pada perlakuan $(\mathrm{g})$

Bp $\quad=$ Berat akhir pada perlakuan $(\mathrm{g})$

\section{Rata-Rata Waktu Kematian}

Waktu kematian dihitung dengan menghitung jumlah keong yang mati sejak satu hari (1 x 24 jam) setelah aplikasi ekstrak, sampai ada unit perlakuan keong mas yang mati mencapai $100 \%$, perhitungan dilakukan dengan menggunakan rumus berikut ini:

$$
\text { Kecepatan waktu kematian }=\frac{\text { Waktu Pengamatan } \times \text { Jumlah yang Mati }}{\text { Jumlah Keong Mas Awal }}
$$

\section{Analisis Data Penelitian}

Data hasil pengamatan pada setiap peubah dianalisis dengan Anova. Jika terdapat perbedaan yang nyata pada Fhit, maka dilanjutkan dengan Uji Beda Nyata Terkecil (BNT) pada taraf 0,05 (Gomez \& Gomez, 1995).

\section{HASIL DAN PEMBAHASAN}

\section{Mortalitas Keong Mas}

Hasil analisis ragam menunjukan bahwa secara mandiri aplikasi faktor konsentrasi ekstrak buah mahkota dewa terhadap mortalitas $P$. canaliculata berbeda sangat nyata, sedangkan faktor lama perendaman ekstrak buah mahkota dewa menunjukan hasil berbeda nyata terhadap mortalitas $P$. canaliculata dan tidak terdapat interaksi antara kedua faktor tersebut. Rata-rata mortalitas keong mas pada berbagai perlakuan konsentrasi ekstrak buah mahkota dewa dan rata-rata lama perendaman ekstrak buah mahkota dewa pada pengamatan 1, 2, dan 3 HSA dapat dilihat pada gambar 4 (a dan b) berikut.

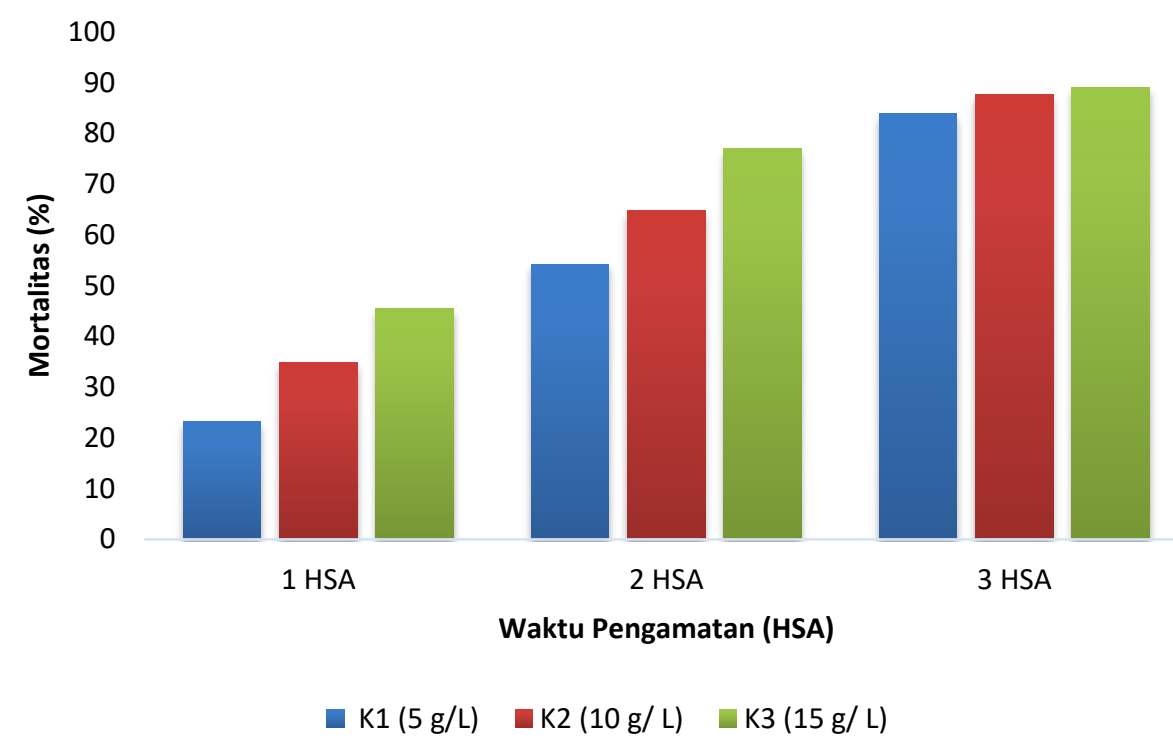


Gambar 4 (a). Rata-rata mortalitas $P$. canaliculata akibat aplikasi konsentrasi ekstrak buah mahkota dewa pada pengamatan 1, 2, dan 3 HSA.

Pada penelitian ini secara tunggal dapat dilihat bahwa aplikasi konsentrasi ekstrak buah mahkota dewa terhadap mortalitas $P$. canaliculata yang terdapat pada Gambar 4a menunjukan, dari 1 sampai dengan 3 HSA terdapat perbedaan yang sangat nyata antar perlakuan K1, K2 dan K3, mortalitas tertinggi terdapat pada K3 yaitu 89,09\% diikuti oleh K2 $87,59 \%$ dan K1 83,88\% pada pengamatan 3 HSA. Tinggi dan rendahnya mortalitas disebabkan oleh tingkat konsentrasi ekstrak buah mahkota dewa dan juga pengaruh senyawa kimia saponin yang terkandung pada buah mahkota dewa, yang mana dapat dilihat pada gambar bahwa semakin tinggi tingkat konsentrasi ekstrak buah mahkota dewa yang diberikan maka semakin tinggi tingkat mortalitas yang dialami oleh keong mas.

Sesuai dengan pendapat Gotama et al (1999) di dalam buah mahkota dewa terkandung senyawa alkaloid, saponin, dan flavonoid, ia juga mengatakan senyawa kimia saponin diklasifikasikan berdasarkan struktur aglikon kedalam triterpenoid dan steroid saponin, yang mana kedua dari senyawa tersebut mempunyai sifat sebagai anti inflamasi, analgesik, dan sitotosik. Keracunan senyawa kimia saponin pada keong mas terjadi akibat proses saponifikasi sehingga daging keong mas menjadi cepat lunak hingga menyebabkan kematian (mortalitas) dan akhirnya terlepas dari cangkangnya (Kurniawati et al, 2007).

Hasil penelitian Nailirrahma (2014) menyatakan ekstrak mahkota dewa efektif menurunkan daya hidup keong mas pada konsentrasi $10 \mathrm{~g} / \mathrm{L}$ dalam kurun waktu pemaparan 72 jam dan mampu menurunkan daya hidup keong mas hingga mencapai $100 \%$ pada perlakuuan konsentrasi $25 \mathrm{~g} / \mathrm{L}$ dalam kurun waktu 48 jam dan 72 jam pemaparan ekstrak.

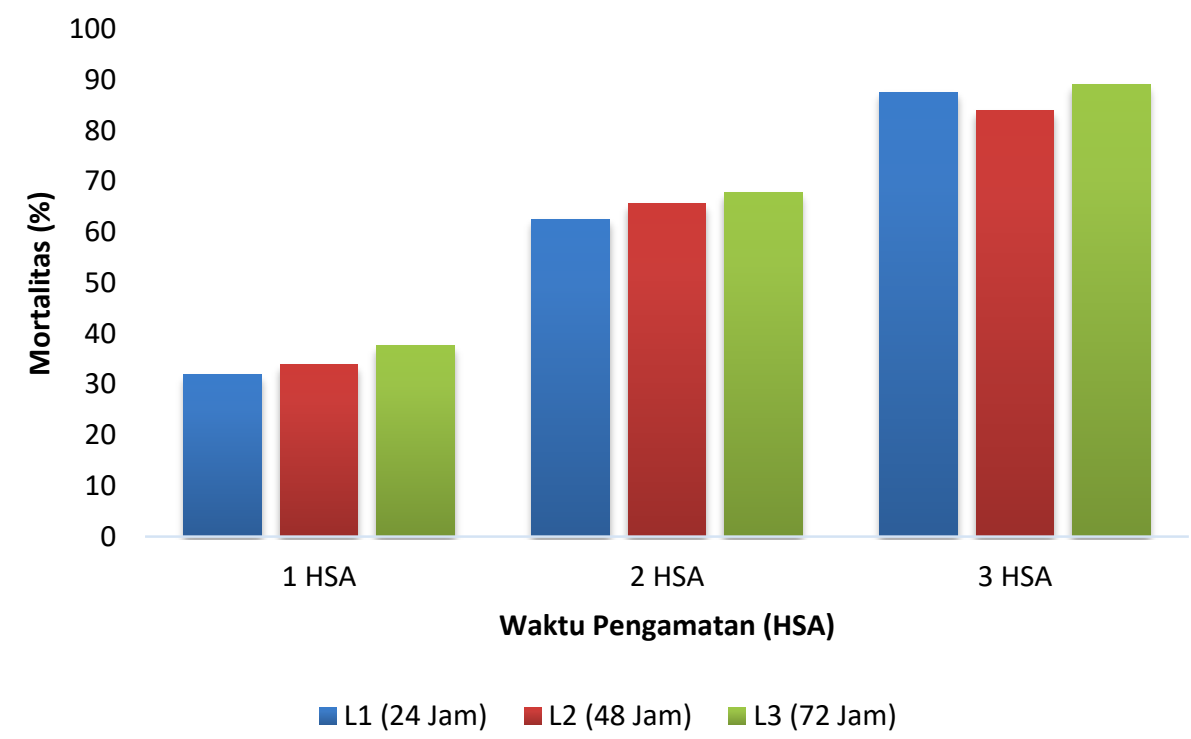

Gambar 4 (b). Rata-rata mortalitas $P$. canaliculata akibat aplikasi lama perendaman ekstrak buah mahkota dewa pada pengamatan 1, 2, dan 3 HSA.

Pada Gambar 4b dapat dilihat bahwa perlakuan L1 (24 jam), L2 (48 jam) dan L3 (72 jam) pada pengamatan 1 dan 2 HSA lama perendaman ekstrak buah mahkota dewa menunjukan bahwa semakin lama perendaman semakin tinggi mortalitas keong mas. Pada pengamatan 3 HSA, mortalitas $P$. canaliculata terendah terdapat pada L2 yaitu 83,88\%, sedangkan mortalitas $P$. canaliculata tertinggi terdapat pada perlakuan L3 yaitu $89,09 \%$ dan diikuti perlakuan L1 yaitu $87,59 \%$. Hal ini diduga karena lama perendaman pada perlakuan 
L2 (48 Jam) di hari ketiga setelah aplikasi mengalami penurunan daya racun yang mana ini dapat disebabkan oleh pengaruh lingkungan sekitar, ini ada kaitannya dengan kelemahan dari biopestisida, menurut Hendayana (2006) daya kerja biopestisida relatif lambat, tidak membunuh organisme secara langsung, tidak tahan disimpan dalam kurun waktu yang lama, dan kepekatan zat racun biopestisida akan memudar jika terkena faktor luar.

Secara keseluruhan dapat dikatakan bahwa mortalitas hama $P$. canaliculata meningkat mulai dari 1 sampai dengan 3 HSA untuk setiap perlakuan. Pada pengamatan 3 HSA mortalitas $P$. canaliculata tertinggi terdapat pada kombinasi perlakuan K3L3 (konsentrasi 15 $\mathrm{g} / \mathrm{L}$ dan lama perendaman $72 \mathrm{jam}$ ) dimana kedua faktor tersebut bernilai yaitu sebesar $89,09 \%$, Sedangkan mortalitas yang paling rendah terdapat pada kombinasi perlakuan K1L2 (konsentrasi $5 \mathrm{~g} / \mathrm{L}$ dan lama perendaman 48 jam) yaitu sebesar 83,88\%. Hal ini ada kaitannya dengan pernyataan Subiakto (2002) dimana ia mengatakan bahwa konsentrasi zat racun yang terkandung didalam larutan sesuai dengan jumlah konsentrasi bahan yang digunakan, jika konsentrasi bahan yang digunakan banyak maka konsentrasi zat racun yang terkandung didalam larutan akan tinggi, begitu juga sebaliknya.

Gejala keracunan pada $P$. canaliculata ditandai dengan adanya sekresi lendir, kemampuan makan menurun, aktivitas hidup rendah, warna kulit mulai memucat, bagian tubuh menjadi lunak, operkulum menutup semakin rapat dan kemudian mengalami kematian. Keracunan saponin pada $P$. canaliculata terjadi akibat proses saponifikasi sehingga daging keong mas atau $P$. canaliculata menjadi lebih cepat lunak (Kurniawati et al, 2007).

\section{Persentase Antifeedant (Penghambat Makan) P. canaliculata}

Hasil analisis ragam menunjukan bahwa aplikasi konsentrasi dan lama perendaman ekstrak buah mahkota dewa terhadap penghambatan makan keong mas $P$. canaliculata pada pengamatan 1, 2, dan 3 HSA (Lampiran 12, 15, dan 18) berbeda nyata dan menunjukan adanya interaksi antara faktor konsentrasi dan lama perendaman ekstrak buah mahkota dewa. Rata-rata penghambat makan keong mas akibat aplikasi konsentrasi dan lama perendaman ekstrak buah mahkota dewa pada 1, 2, dan 3 HSA dapat di lihat pada tabel berikut ini.

Tabel 2. Rata-rata penghambat makan keong mas akibat perlakuan konsentrasi dan lama perendaman ekstrak buah mahkota dewa pada pengamatan 1, 2, dan 3 HSA.

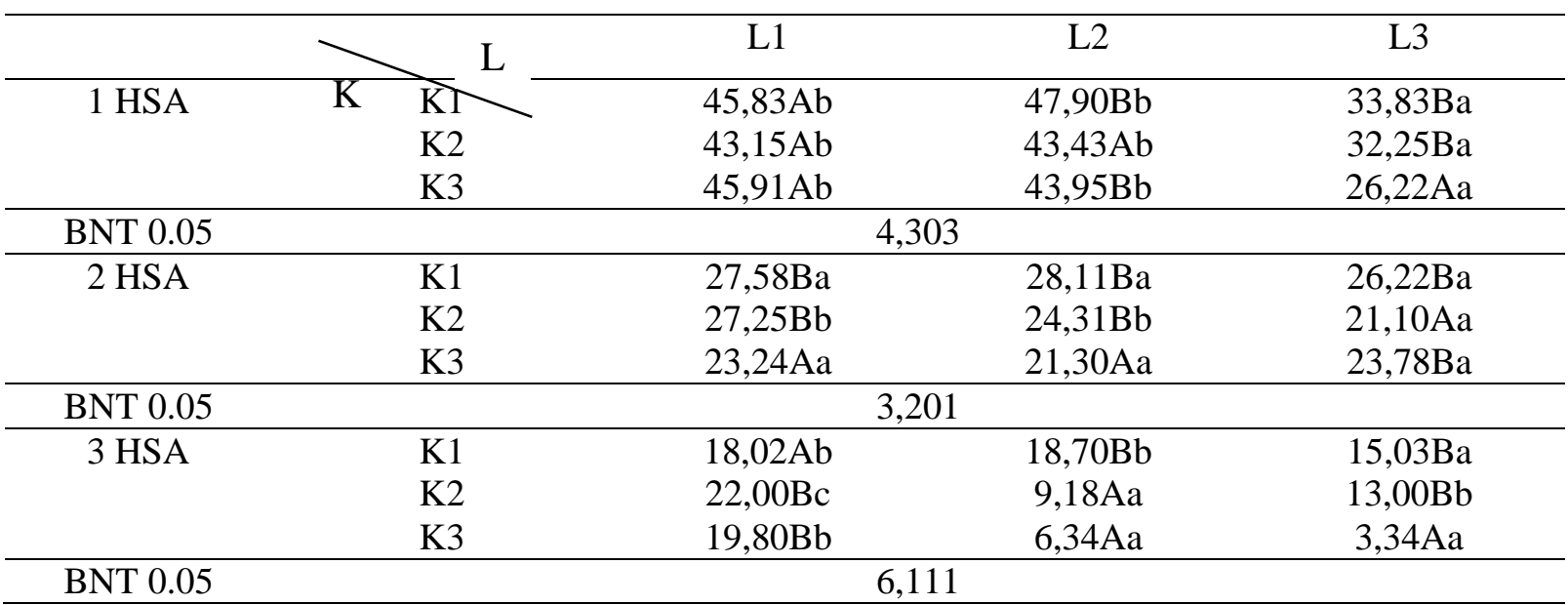

Tabel 2 menunjukan bahwa rata-rata presentase penghambat makan keong mas akibat aplikasi perlakuan konsentrasi dan lama perendaman ekstrak buah mahkota dewa terdapat perbedaan nyata pada pengamatan 1 dan 2 HSA dan perbedaan yang sangat nyata pada pengamatan 3 HSA. Interaksi antara konsentrasi molusisida nabati dan lama perendaman dapat dilihat pada gambar 5, 6 dan 7. 


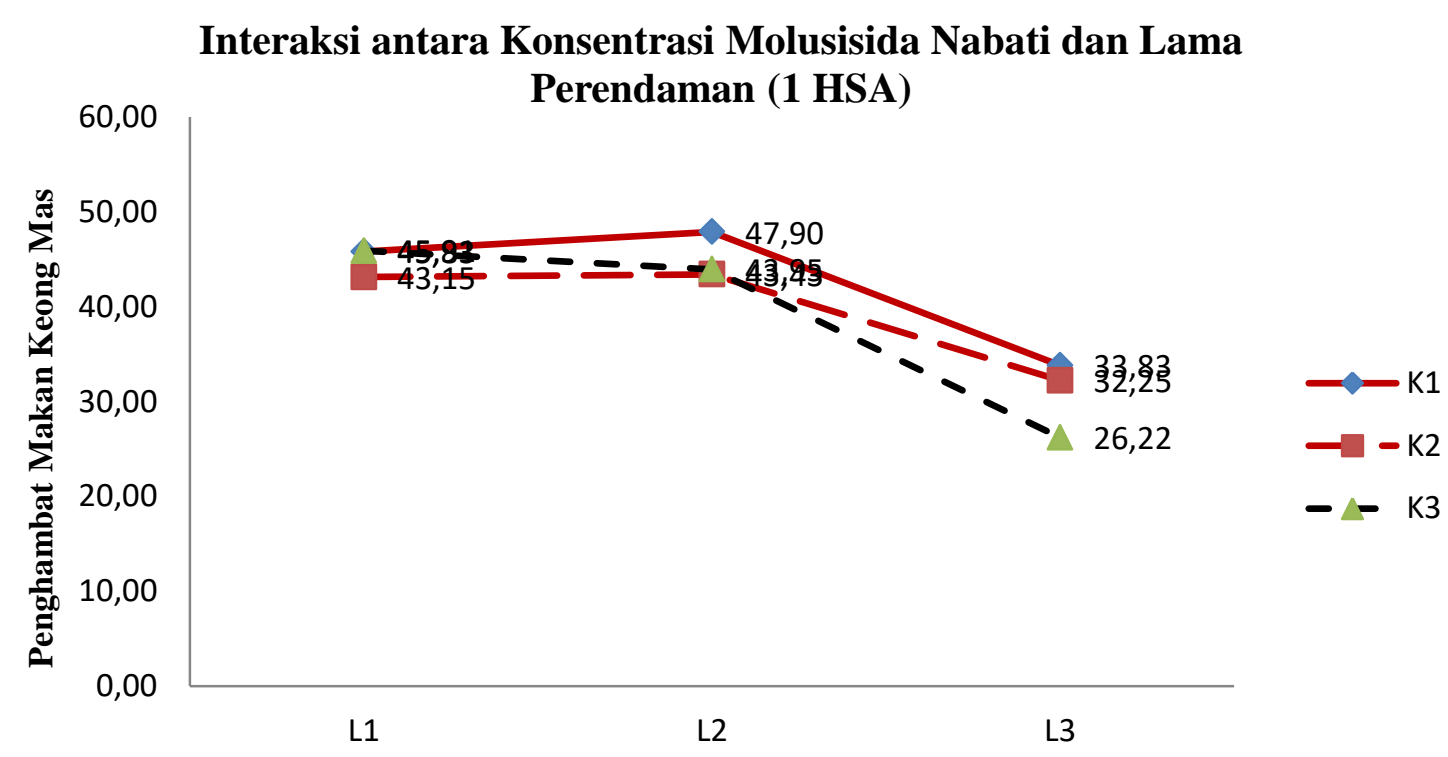

Gambar 5. Rata-rata persentase Antifeedant (penghambat makan) keong mas akibat aplikasi kombinasi perlakuan konsentrasi serta lama perendeman ekstrak buah mahkota dewa pada pengmatan 1 HSA.

\section{Interaksi Konsentrasi Molusisida Nabati dan Lama Perendaman (2 HSA)}

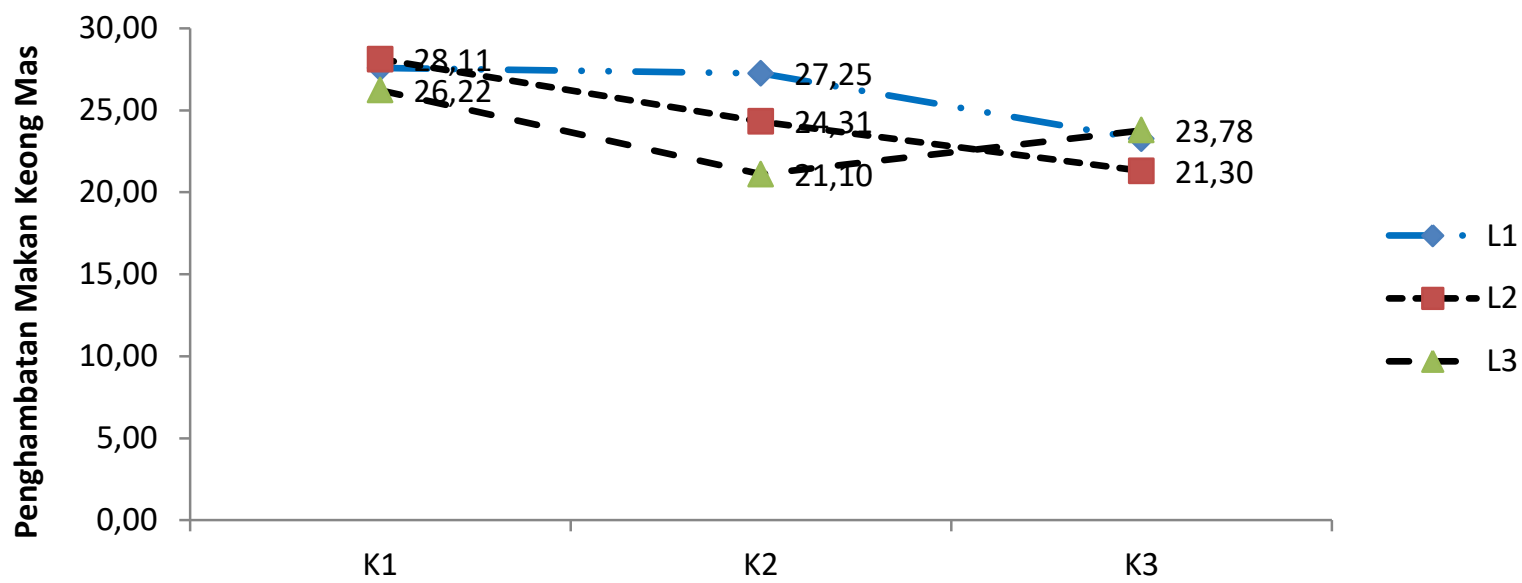

Gambar 6. Rata-rata persentase Antifeedant (penghambat makan) keong mas akibat aplikasi kombinasi perlakuan konsentrasi serta lama perendeman ekstrak buah mahkota dewa pada pengmatan 2 HSA. 


\section{Interaksi Konsentrasi Molusisida Nabati dan Lama Perendaman (3 HSA)}

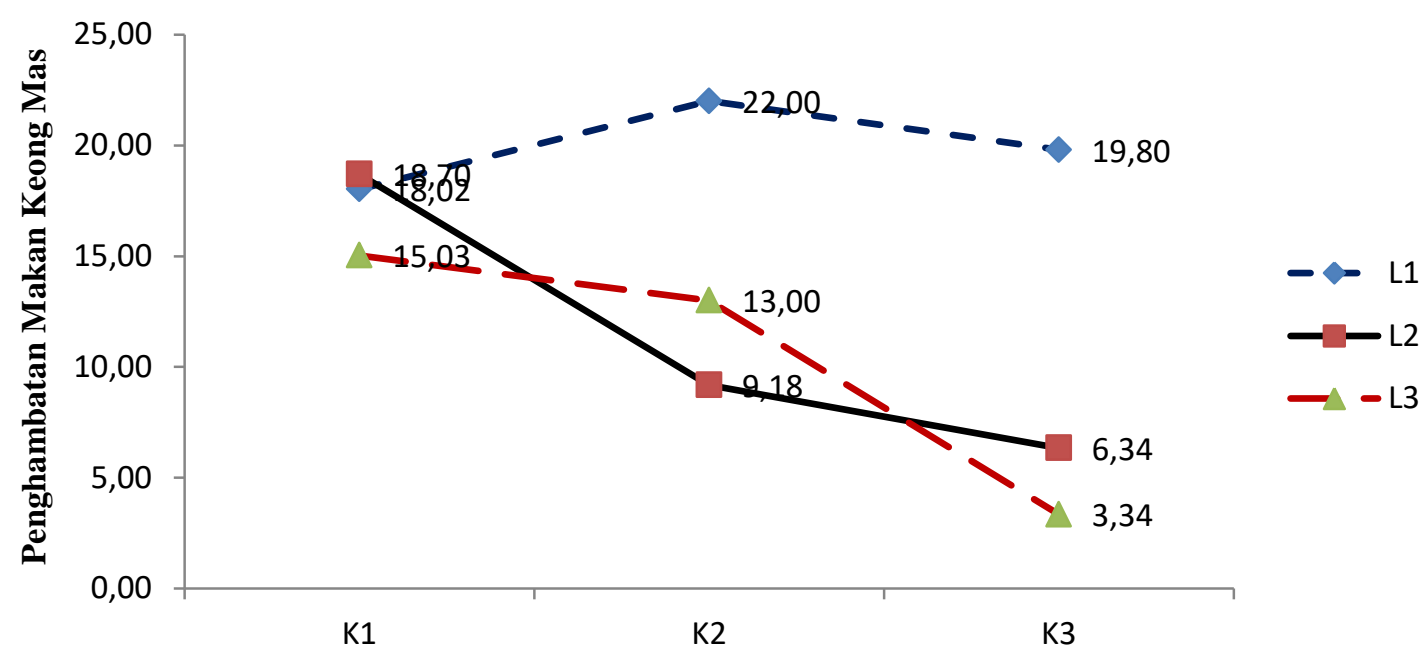

Gambar 7. Rata-rata persentase Antifeedant (penghambat makan) keong mas akibat aplikasi kombinasi perlakuan konsentrasi serta lama perendeman ekstrak buah mahkota dewa pada pengmatan 3 HSA.

Pada gambar 5 pengamatan 1 HSA persentase penghambatan makan tertinggi terdapat pada kombinasi perlakuan K1L2 (Konsentrasi $5 \mathrm{~g} / \mathrm{L}$ dan lama perendaman 48 Jam), yaitu sebesar 47,90\%, yang diikuti oleh kombinasi perlakuan K3L1 (Konsentrasi $15 \mathrm{~g} / \mathrm{L}$ dan lama perendaman $24 \mathrm{Jam}$ ) sebesar $45,91 \%$. dan yang paling rendah terdapat pada kombinasi perlakuan K3L3 (Konsentrasi $15 \mathrm{~g} / \mathrm{L}$ dan lama Perendaman $72 \mathrm{Jam}$ ) yaitu sebesar 26,22\%. Pada gambar 6 di pengamatan 2 HSA persentase penghambatan makan tertinggi terdapat pada kombinasi perlakuan K1L2 (Konsentrasi $5 \mathrm{~g} / \mathrm{L}$ dan lama perendaman $48 \mathrm{Jam}$ ), yaitu sebesar $28,11 \%$, yang diikuti oleh kombinasi perlakuan K1L1 (Konsentrasi $5 \mathrm{~g} / \mathrm{L}$ dan lama perendaman $24 \mathrm{Jam}$ ) sebesar $27,58 \%$. dan yang paling rendah terdapat pada kombinasi perlakuan K2L3 (Konsentrasi $10 \mathrm{~g} / \mathrm{L}$ dan lama Perendaman $72 \mathrm{Jam}$ ) yaitu sebesar 21,10\%. Pada gambar 7 di pengamatan 3 HSA persentase penghambatan makan tertinggi terdapat pada kombinasi perlakuan K2L1 (Konsentrasi $10 \mathrm{~g} / \mathrm{L}$ dan lama perendaman $24 \mathrm{Jam}$ ), yaitu sebesar 22,00\%, yang diikuti oleh kombinasi perlakuan K3L1 (Konsentrasi 15 g/L dan lama perendaman $24 \mathrm{Jam}$ ) sebesar 19,80\%. dan yang paling rendah terdapat pada kombinasi perlakuan K3L3 (Konsentrasi $10 \mathrm{~g} / \mathrm{L}$ dan lama Perendaman $72 \mathrm{Jam}$ ) yaitu sebesar 3,34\%.

Pada pengamatan yang telah dilakukan dari 1 sampai dengan 3 HSA persentase penghambat makan yang terjadi pada keong mas mengalami penurunan disetiap perlakuan yang dilakukan. Hal ini menunjukan bahwa tinggi rendahnya persentase peghambat makan yang terjadi pada keong mas tegantung pada jumlah konsentrasi dan lama perendaman yang diberikan, selain itu penghambatan makan juga sangatlah bergantung kepada seberapa banyak jumlah keong mas yang masih hidup. Secara umum dapat dikatakan bahwa persentase penghambat makan terendah terdapat pada kombinasi perlakuan K3L3 (Konsentrasi $15 \mathrm{~g} / \mathrm{L}$ dan Lama perendaman $72 \mathrm{Jam}$ ) di pengamtan 1 dan 3 HSA jika di bandingkan dengan perlakuan lainnya, sedangkan pada pengamatan 2 HSA persentase penghambat makan terendah terdapat pada kombinasi perlakuan K2L3 (Konsentrasi $10 \mathrm{~g} / \mathrm{L}$ dan lama perendaman 72 jam), hal ini ada kaitannya dengan jumlah keong mas yang tersisa pada penelitian yang dilakukan. 
Pemberian ekstrak mahkota dewa yang bersifat toksik secara umum dapat menggangu proses akitivitas makan dan daya hidup keong mas, dikarenakan tanaman mahkota dewa mengandung senyawa-senyawa seperti saponin, flavonoid, dan juga alkaloid yang mana senyawa-senyawa tersebut dapat bersifat sebagai penghambat makan.

Senyawa saponin sendiri dapat mempengaruhi sistem metabolisme yang terdapat pada keong mas, sistem metabolisme yang terganggu adalah pada sistem saraf pusat dan pada sistem pernapasannya. Saponin yang masuk ke dalam sistem saraf pusat akan menyebabkan kelumpuhan pada keong mas (Chomsum dan Muhfahroyin, 2013).

\section{Rata-rata kecepatan waktu kematian $P$. canaliculata}

Hasil analisis ragam menunjukan bahwa aplikasi konsentrasi ekstrak buah mahkota dewa berbeda sangat nyata terhadap kecepatan waktu kematian keong mas $P$. canaliculata dan sedangkan lama perendaman ekstrak buah mahkota dewa berbeda tidak nyata terhadap kecepatan waktu.

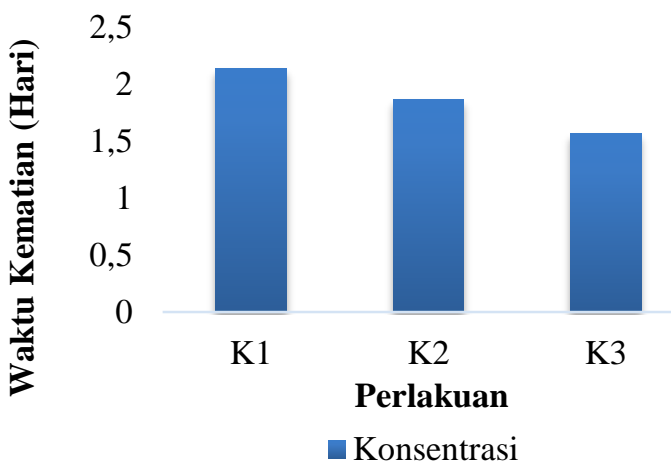

Gambar 8a. Rata-rata waktu kematian $P$. canaliculata akibat aplikasi konsentrasi ekstrak buah mahkota dewa pada pengamatan 1, 2, dan 3 HSA.

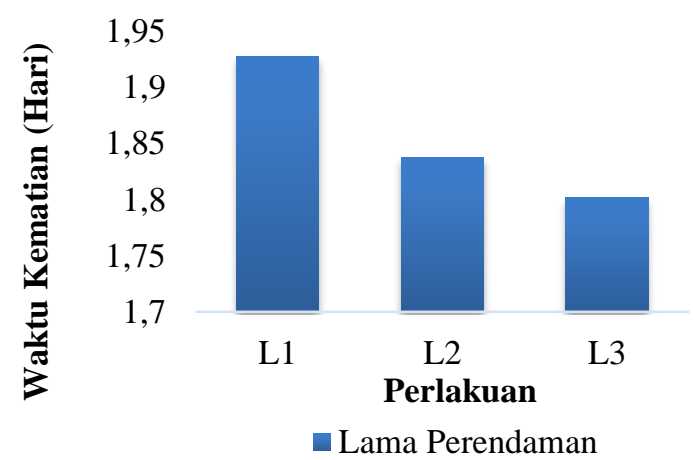

Gambar 8b. Rata-rata waktu kematian $P$. canaliculata akibat aplikasi lama perendaman ekstrak buah mahkota dewa pada pengamatan 1, 2, dan 3 HSA.

Pada gambar 8a menunjukan bahwa rata-rata kecepatan waktu kematian keong mas pada perlakuan konsentrasi K3 lebih efektif dibadingkan dengan perlakuan konsentrasi yang lain. Pada perlakuan K3 menunjukan bahwa semakin tinggi konsentrasi ekstrak mahkota dewa yang digunakan maka kecepatan waktu kematian pun akan semakin singkat dan efektif. Pengaruh molusisida dari ekstrak buah mahkota dewa terlihat jelas terhadap waktu kematian yang dialami keong mas, hal ini dikarenakan senyawa kimia yang terkandung didalam ekstrak buah mahkota dewa tersebut.

Ishaaya (2006) megatakan bahwa senyawa aktif dari buah mahkota dewa berperan sebagai racun perut dengan senyawa aktifnya antara lain alkaloid, flavoloid, dan saponin. Senyawa saponin berpengaruh terhadap aktivitas enzim pada sistem pencernaan dan penyerapan makanan. Dari pernyataan diatas dapat dikatakan bahwa semakin tinggi konsentrasi ekstrak buah mahkota dewa yang diberikan maka daya hidup keong mas akan semakin menurun dan waktu kematian pun menjadi semakin singkat dikarenakan daya hidup yang terganggu oleh kandungan senyawa kimia saponin yang bersifat toksik. 
Pada gambar 8b. menunjukan bahwa rata-rata kecepatan waktu kematian keong mas pada perlakuan konsentrasi L3 lebih efektif dibadingkan dengan perlakuan lama perendaman yang lain. Pada perlakuan L3 menunjukan bahwa semakin lama waktu perendaman ekstrak buah mahkota dewa yang digunakan maka rata-rata kecepatan waktu kematian pun akan semakin efektif. Selain itu juga kualitas air yang keruh kuning kecoklatan setelah aplikasi juga dapat menyebabkan keong mas mengalami kematian. Perlu diketahui pula ekstrak buah mahkota dewa yang telah mengalami perendaman selama 72 jam berwarna lebih pekat dari ekstrak lainnya yang hanya direndam dalam kurun waktu 24 sampai 48 jam, hal ini menyebabkan pada media percobaan yang diberikan perlakuan L3 air menjadi lebih keruh. dikarena air setelah aplikasi berwarna keruh, menurut Susanto (dalam Gassa, 2011) mengatakan bahwa, keong mas menyukai lingkungan yang jernih, pada dasarnya keong mas dapat tumbuh baik dengan adanya sirkulasi air pada habitatnya yang terus berganti-ganti sehingga zat-zat berbahaya akan ikut terbawa air yang mengalir. Sehingga kualitas air memberikan pengaruh besar terhadap kehidupan dan pertumbuhan organisme dalam air.

\section{KESIMPULAN DAN SARAN}

Penggunaan ekstrak buah mahkota dewa sebagai molusisida nabati dengan konsentrasi $15 \mathrm{~g} / \mathrm{l}$ air dan lama perendaman 72 jam (K3L3) efektif untuk menurunkan daya hidup (motalitas) keong mas hingga mencapai $89,09 \%$ dan yang persentase mortalitas terendah terdapt pada kombinasi perlakuan K2L1. Penghambat makan keong mas tertinggi terdapat pada kombinasi perlakuan K1L2 dengan persentase nilai $47,90 \%$ dan yang terendah terdapat pada perlakuan K3L3 dengan persentase nilai 26,22\%. Kecepatan waktu kematian keong mas setelah dilakukan pengaplikasian menggunakan ekstrak buah mahkota dewa berkerja efektif pada perlakuan kosentrasi K3 dengan rata-rata waktu 1,567 dan lama perendaman berkerja efektif pada perlakuan L3 dengan rata-rata waktu 1,802

\section{DAFTAR PUSTAKA}

Arsyadana. 2014. Efektivitas Biopestisida Biji Mahkota Dewa (Phaleria Macrocarpa) Dengan Lama Fermentasi Yang Berbeda Dalam Mengendalikan Hama Keong Mas (Pomacea Canaliculata) Pada Tanaman Padi (Oryza Sativa L). Karya Ilmiah. Surakarta: Universitas Muhammadiyah Surakarta.

Chosum, S Dan Muhfahroyin. 2013. Pengaruh Variasi Konsentrasi Buah Mengkudu (Morinda citrifolia) Terhadap Mortalitas Hama Keong Mas (Pomacea caniculata L.) Sebagai Sumber Belajar Biologi. Skripsi. Lampung: Fakultas Keguruan dan Ilmu Pendidikan, Universitas Muhammadiyah Metro.

Cowie RH. 2003. Apple Snail (Ampullaridae) as Agricultural Pest: Their Biology, Impacts, And Management. Molluscs As Crop Pest. Wallingford (US): CABI Publishing.

Direktorat Perlindungan Tanaman Pangan. 2008. Luas Serangan Siput Murbai Pada Tanaman Padi Tahun 1997-2006, Rerata 10 Tahun Dan Tahun 2007. Direktorat Jenderal Tanaman Pangan. Jakarta.

Djojosumarto, P. 2008. Teknik Aplikasi Pestisida Pertanian Edisi Revisi. Kanisus. Yogyakarta. 
Gassa, A. 2011. Pengaruh Buah Pinang (Areca catechu) terhadap Mortalitas Keong Mas (Pomacea caniculata) pada Berbagai Stadia. J. Fitomedika. Vol 7. 171-174.

Gomez, K. A. \& A. A. Gomez. 1995. Prosedur Statistik Untuk Penelitian Pertanian. Ahli Bahasa: E. Syamsuddin \& J. S. Baharsya, Universitas Indonesia. Jakarta.

Gotama, I.B., 1999, Inventaris Tanaman Obat 5. Departemen kesehatan Badan Penelitian dan Pengembangan Kesehatan. Jakarta.

Hendarsih, S dan Kurniawati, N. 2009. Keong Mas Dari Hewan Peliharaan Menjadi Hama Utama Padi Sawah. Artikel. Penelitian Balai Besar Tanaman Padi.

Hendayana, S. 2006. Kimia Pemisah Kromotografi dan Eletroforesis Modern. PT Remaja Rosdakarya. Bandung.

Isman, MB. 2008. Perspective Botanical Insecticides: For Richer For Poorer. Pest Manag Sci.

Kertosaputro, D., N. Kurniawati, H. Suharto. Dan W. Hidayat. 2007. Bahan nabati yang Dapat Digunakan sebagai Moluskisida Pada Keong Mas (Pomacea Canaliculata L). Apresiasi Hasil Penelitian. Balai Besar Penelitian Tanaman Padi.

Kurniawati, N., W. Hidayat, H. Suharto. 2007. Daya Tetas Dan Daya Hidup Keong Mas Pada Perlakuan Pestisida Nabati Dan Insektisida. Prosiding Seminar Apresiasi Hasil Penelitian Padi Menunjang P2BN, Buku 1. Hal 393-402. BB Padi.

Nailirrahma. 2014. Efektivitas Ekstrak Daun Mahkota Dewa Dan Daun Mengkudu Sebagai Moluskisida Nabati Terhadap Daya Hidup Keong Mas (Pomacea canaliculata Lamarck). Skripsi. Bogor: Institut Pertanian Bogor.

Subiakto, S. 2002. Pestisida Nabati Pembuatan dan Pemanfaatan. Balai Penelitian Tanaman Holtikultura.

Suharto H. 2002. Golden Apple Snail, Pomacea Canaliculata In Indonesia. Proceedings Of The Meeting Of The Special Working Group On The Golden Apple Snail (Pomacea Spp.) At The Seventh International Congress On Medical and Applied Malacology (7th ICMAM) Los Baños (PH): SEAMEO Regional Center For Graduate Study And Research In Agriculture.

Sumastuti, R. 2009. Efek Sitotoksik Ekstrak Buah Mahkota Dewa dan Daun Mahkota Dewa (Phaleria Macrocarpa (Scheff). Boerl) terhadap Sel Hela. Artikel. Yogyakarta: Fakultas Kedokteran, Universitas Gajah Mada. 